\title{
Hayat Bilgisi ve Sosyal Bilgiler Derslerinde Uzaktan Eğitim Sürecine Yönelik Veli Tutumları ve Teknolojiye Karşı Dirençlerinin İncelenmesi
}

\author{
Nur ÜTKÜR GÜLLÜHAN \\ İstanbul Üniversitesi-Cerrahpaşa \\ nur.utkur@iuc.edu.tr
}

Gönderilme Tarihi: 09/03/2021

Kabul Tarihi: 30/07/2021

Yayınlanma Tarihi: 30/07/2021

\begin{tabular}{|c|c|}
\hline Makale Bilgileri & ÖZET \\
\hline $\begin{array}{l}\text { Anahtar Kelimeler: } \\
\text { Uzaktan eğitim, } \\
\text { Teknolojiye karş1 } \\
\text { direnç, } \\
\text { Teknolojiye yönelik } \\
\text { tutum, } \\
\text { Veliler }\end{array}$ & $\begin{array}{l}\text { Araştırmanın genel amacı, ilkokula devam eden öğrenci velilerinin uzaktan } \\
\text { hayat bilgisi ve sosyal bilgiler eğitimi süreci ile ilgili görüşlerinin çeşitli } \\
\text { değişsenlere yönelik olarak belirlenmesidir. Bu amaca yönelik hazırlanan } \\
\text { çalışmada nicel araştırma desenlerinden tarama modeli kullanılmıstır. Devlet } \\
\text { okulunda öğrenim gören ilkokul öğrencilerinin velilerinden } 201 \text { kişi araştırma } \\
\text { örneklemini oluşturmuştur. Araştırmada veri toplama aracı olarak Ailelerin } \\
\text { Teknoloji ve Derslerde Teknoloji Kullanımına Yönelik Tutum Ölçeği ve } \\
\text { Teknolojiye Karşı DirençÖlçeği kullanılmıştır. Elde edilen verilerin analizi SPSS } \\
\text { ile yapilmıştır. Çalışmada velilerin derslerde teknoloji kullanımına yönelik } \\
\text { tutumlarını olumlu düzeyde olduğu ve teknolojiye karşı gösterdikleri } \\
\text { dirençlerin de orta düzeyde olduğu söylenebilir. Cinsiyet değişkenine göre } \\
\text { incelendiğinde; kadınların ortalama tutum puanlarının erkeklere oranla daha } \\
\text { yüksek olduğu ve teknolojiye karşı direnç puan ortalamalarının erkeklerinkiyle } \\
\text { eşit olduğu görülmektedir. Eğitim düzeyi değişkenine göre, ölçek toplam } \\
\text { puanında teknolojiye yönelik veli tutumları anlamlı olarak değişim } \\
\text { göstermezken, teknolojiye karşı direnç ölçek toplam puanında anlamll bir } \\
\text { değisisim mevcuttur. Uzaktan hayat bilgisi ve sosyal bilgiler öğretiminin niteliği } \\
\text { değişkenine göre ise, ölçek boyutlarında teknolojiye yönelik veli tutumları } \\
\text { anlamlı olarak değişkenlik gösterirken, teknolojiye karşı direnç ölçek toplam } \\
\text { puanında anlamlı bir değişim söz konusu değildir. Ayrıca velilerin derslerde } \\
\text { teknoloji kullanıma yönelik tutum ve teknolojiye karşı dirençleri arasındaki } \\
\text { ilişki incelendiğinde, dirençleri arttıkça tutumlarında azalma olduğu } \\
\text { görülmektedir. }\end{array}$ \\
\hline
\end{tabular}

Ütkür Güllühan, N. (2021). Hayat bilgisi ve sosyal bilgiler derslerinde uzaktan eğitim sürecine yönelik veli tutumları ve teknolojiye karşı dirençlerinin incelenmesi. Gazi Ĕ̆gitim Bilimleri Dergisi, 7(2), 155-177. https://dx.doi.org/10.30855/gjes.2021.07.02.003

Dergi Web Sayfası: http://dergipark.gov.tr/gebd 


\section{Investigation of Parents' Attitudes towards Distance Education Process and Their Resistance to Technology in Life Sciences and Social Studies Courses}

\begin{tabular}{|c|c|}
\hline Article Info & ABSTRACT \\
\hline $\begin{array}{l}\text { Keywords: } \\
\text { Distance education, } \\
\text { Resistance to } \\
\text { technology, } \\
\text { Attitude towards } \\
\text { technology, } \\
\text { Parents }\end{array}$ & $\begin{array}{l}\text { The general purpose of the research, it is the determination of the opinions of } \\
\text { the parents of students attending primary school about the distance life studies } \\
\text { and social studies education process in terms of various variables. In the study } \\
\text { prepared for this purpose, the survey model, one of the quantitative research } \\
\text { designs, was used. } 201 \text { parents of primary school students studying in public } \\
\text { schools constituted the research sample. As a data collection tool in research; } \\
\text { "Parents' Attitude Scale Regarding Technology and Use of Technology in } \\
\text { Classes" and "Resistance Scale to Technology" were used. The analysis of the } \\
\text { obtained data was made with the SPSS program. In the study, it can be said that } \\
\text { the parents' attitudes towards the use of technology in lessons are at a positive } \\
\text { level and their resistance to technology is at a moderate level. When analyzed } \\
\text { according to gender variable, it is observed that the average attitude scores of } \\
\text { women are higher than that of men, and the mean scores for resistance to } \\
\text { technology are equal to that of men. According to the education level variable, } \\
\text { while parents' attitudes towards technology did not change significantly in the } \\
\text { scale total score, there was a significant change in the technology resistance scale } \\
\text { total score. According to the variable of the quality of distance life studies and } \\
\text { social studies teaching, parents' attitudes towards technology vary significantly } \\
\text { in scale dimensions, while there is no significant change in the total score of the } \\
\text { scale of resistance to technology. In addition, when the relationship between } \\
\text { parents' attitude towards technology use in lessons and their resistance to } \\
\text { technology is examined, it is seen that their attitudes decrease as their resistance } \\
\text { increases. }\end{array}$ \\
\hline
\end{tabular}

\section{GİRIŞ}

Dünyadaki çeşitli ülkelerde yüz yüze eğitimin yanı sıra senelerdir, uzaktan eğitimin de var olduğu bilinmektedir. Uzaktan eğitim, farklı koşullar içerisinde olan insan topluluklarının faydalanabilmesini, insanın kendi kendine öğrenmesini ve öğrenen bireyde sorumluluk bilincini geliştirmeyi amaçlamaktadır (Hızal, 1983).

Hayatını uzaktan eğitime adayan bir eğitimci olan Wedemeyer'ın (1961) esas amacı, geleneksel olmayan ve "kapıların arkasındaki eğitime" odaklanılmayan bir eğitim anlayışı ortaya koymaktadır. Bu eğitim anlayışı, davranışçı yaklaşımın tam olarak tersi bir anlayışı savunmaktadır. Hümanist yaklaşımı temele alan bu yaklaşımda teknolojinin eğitime entegre edilmesi amaçlanmıştır. Temel ilke olarak ise, öğrenen merkezli eğitime vurgu yapılmıştır. Wedemeyer'a (1961) göre, uzaktan eğitim yaygınlaşırsa, öğrenciler bütün hayatları boyunca bağımsız öğrenenler" olarak yaşayabileceklerdir. Bunu "öz-yönelimli öğrenme" olarak da adlandıran Wedemeyer, yüz yüze devam eden geleneksel eğitime çok daha iyi bir alternatif olarak uzaktan eğitimi savunmaktadır (Akt. Diehl, 2013). 
Dünyada ortaya çıkan COVID-19 salgını sonucu, tüm dünyayla birlikte ülkemizde de 2019-2020 eğitim-öğretim yılı bahar yarıyılı itibariyle ilkokul, ortaokul, lise ve üniversite düzeylerinde eğitime bir süre ara verilip daha sonra uzaktan eğitim ile senkron ve asenkron yöntemlerle yürütülmeye başlanmıştır (UNESCO, 2020). COVID-19 salgını, öğrencilerin yalnızca eğitimlerinde değil, aynı zamanda sosyal hayatla ilişkili olarak da hayatlarında bazı sorunlara yol açmıştır. Ayrıca bu süreç, öğrenciler ve veliler için endişe taşıyan bir süreçtir. Çünkü hayatın ne zaman normale döneceği konusunda belirsizliğin olması, öğrenci ve velilerdeki kaygıyı artırmaktadır. Öğrencilerin kendilerini güvende hissetmelerinin yanı sıra, velilerin de bu güveni hissetmelerini sağlayabilmek okulların ve öğretmenlerin görevleri arasında yer almaktadır (Daniel, 2020).

Eğitimdeki en önemli paydaşlardan biri olan velilerin, salgın sürecinde daha çok evde öğrenme disiplininin olmaması, çocuklarının evde öğrenmesine yardımcı olmak için daha fazla zaman harcanmasına yönelik bazı sorunlarının olduğu belirlenmiştir. Özellikle ilkokulda 4. sınıfın altındaki çocuklar için, uzaktan eğitim ile öğrenme potansiyelini engelleyen teknoloji becerilerinin eksikliğinin sorun taşıdığı veliler tarafından ortaya konulmuştur (Putri vd., 2020). Dolayısıyla salgın süreciyle birlikte derslerin uzaktan eğitimle işlenmeye başlanmasından sonra, bu derslerin nasıl devam ettiğinin velilerin görüşleri bakımından incelenmesi önem taşımaktadır. Çünkü ilkokul seviyesindeki öğrencilerin alan dersleri olan bu derslerin uzaktan olarak işlenmesi sürecinde, özellikle teknoloji kullanımı kısmında neler yaşadıklarının ele alınması önemli bir faktördür. Çalışmada velilerin tutum ve dirençlerinin incelenmesinin sebebi ise, özellikle küçük yaş gruplarında teknoloji kullanımında velilerin gözetiminin önem taşımasıdır. Bu konuda yapılan çalışmalar literatürde bulunmaktadır (Livingstone ve Helsper, 2008; Rosen, Cheever ve Carrier, 2008). Bu çalışmalarda da ifade edildiği üzere, veliler çocukların internet, bilgisayar ve teknoloji kullanımı süreçlerinde birtakım risklerle karşılaşılmasını büyük oranda engellemektedirler.

Uzaktan eğitim sürecinde teknoloji kullanımı ve teknolojinin eğitime nitelikli biçimde entegre edilmesi oldukça önem taşımaktadır. Özellikle teknolojiyi nitelikli biçimde eğitimin içerisine yerleştirebilen öğrencilerin akademik anlamda başarıya ulaştığı görülmektedir. Örneğin Gür'ün (2017) çalışmasında, “evinde bilgisayarı ve interneti olan öğrencilerin olmayanlara göre Türkçe, matematik, sosyal bilgiler, fen ve teknoloji, ingilizce, din kültürü ve ahlak bilgisi ve bilişim teknolojileri dersi puanlarının anlamlı düzeyde daha yüksek olduğu görülmektedir."

İlkokuldaki temel derslerden olan hayat bilgisi derslerinde, öğrencilere "birey, toplum ve doğa ekseninde temel bilgi, beceri ve değerler kazandırmak" amaçlanırken; sosyal bilgiler derslerinde "vatanını ve milletini seven, haklarını bilen ve kullanan, sorumluluklarını yerine 
getiren, millî bilince sahip birer vatandaş yetiştirmek" hedeflenmektedir (MEB, 2018a; MEB, 2018b). Bu dersler, çocuğun hayatında önem taşıyan sosyal içerikli derslerdir.

Özellikle yaşanılan salgın süreciyle birlikte, ezbere öğretime yatkın olan bu derslerin öğretiminde birtakım sorunlar meydana gelebilmektedir. Çünkü sosyal bilimler içerikli bu dersler, yaşamın içinden unsurları içeriğinde barındıracak şekilde işlenmeli; çocukların "küçük birer tarihçi" gibi aktif biçimde çalışmalarına izin verilmelidir (Kabapınar, 2012). İlkokul düzeyindeki temel alan derslerinden olan hayat bilgisi ve sosyal bilgiler gibi gerçek yaşamla ilişkilendirilen bu derslerin, sınıf ortamında çeşitli aktif öğretim yöntem ve teknikleri kullanılarak işlenmesi, öğrencilerin bu derslerdeki sosyal olguları içselleştirmelerine olanak sağlaması bakımından önemlidir (Ütkür, 2016). İlkokul seviyesindeki çocukların gerçek yaşamla ilgili sosyal olguları öğrendikleri bu derslerin uzaktan eğitimle, öğrencilerin aktif biçimde çalışmalarına olanak vermeyecek şekilde işlenmesi bu derslerin doğası gereği istenmeye bir durumdur. Bu nedenle hayat bilgisi ve sosyal bilgiler derslerinin ezbere öğretimden uzak tutularak, çeşitli öğretim yöntem ve tekniklerinin de kullanılarak nitelikli biçimde işlenmeleri, çocukların hayata dair öğrendiklerinin kalııılığı açısından önem taşımaktadır. Bubb ve Jones'un (2020) çalışmasında salgın sürecinde teknolojinin kullanılarak ders işlenmesinin, öğretmenlere tüm öğrencileri rahatça görmeleri ve duymaları için yeni fırsatlar sağlamakta olduğu ifade edilmektedir. Bu şekilde işlenen dersler sayesinde öğretmenler, sadece sınıfta her zaman parmak kaldıranların değil, tüm öğrencilerin ne kadar kapasiteleri olduğunu anlayabilmektedirler. Bu nedenle uzaktan eğitimde, hayat bilgisi ve sosyal bilgiler gibi sosyal içerikli derslerde bile öğrenciler daha aktif bir konuma getirilebilmektedir.

Literatürde uzaktan eğitim sürecinde teknoloji kullanımına yönelik olarak yapılan çalışmalar (Adıgüzel, 2020; Aslan ve Kan, 2017; Başaran, Doğan, Karaoğlu ve Şahin, 2020; Berson ve Berson, 2005; Bisgin, 2014; Çalışkan, 2019; Dargut ve Çelik, 2014; Fauzi \& Khusuma, 2020; Genç, 2020; Murphy ve Beggs, 2003; Reimers ve Schleicher, 2020), teknoloji kullanımına yönelik olarak veli görüşlerinin incelendiği çalışmalar (Akbulut-Ünal, 2020; Bubb ve Jones, 2020; Çetinkaya ve Sütçü, 2016; Daniel, 2020; Fidan ve Çelik, 2020; Garbe, Ogurlu, Logan ve Cook, 2020; Gür, 2017; İnci-Kuzu, 2020; Odabaş1, 2005; Putri vd., 2020; Türel ve Gül, 2019) bulunmaktadır. Ancak, hayat bilgisi ve sosyal bilgiler derslerinde teknoloji kullanımına yönelik veli tutumlarının ve velilerin teknolojiye karşı dirençlerinin bir arada incelendiği tarama modelinde bir çalışmaya rastlanmamıştır. Bu araştırmada, birden fazla değişken ele alınarak (cinsiyet, eğitim düzeyi, uzaktan eğitimde hayat bilgisi ve sosyal bilgiler derslerinin niteliği), salgın sürecinde ilkokul öğrenci velilerinin, çocuklarının uzaktan eğitimi sürecinden nasıl etkilendiklerinin geniş bir perspektifle incelenmesinin literatüre katkıları olacağı düşünülmektedir. 
Bu doğrultuda çalışmanın genel amacı; ilkokula devam eden öğrenci velilerinin uzaktan hayat bilgisi ve sosyal bilgiler eğitimi sürecine yönelik görüşlerinin ve teknolojiye karşı dirençlerinin farklı değişkenlere göre incelenmesidir. Bu amaçla aşağıdaki sorulara yanıt aranmıştır:

Öğrenci velilerinin;

1. Derslerde teknoloji kullanımına yönelik tutumları ve teknolojiye karşı dirençleri ne düzeydedir?

2. Cinsiyet değişkenine göre derslerde teknoloji kullanımına yönelik tutum ve teknolojiye karşı direnç puanları anlamlı farklılık göstermekte midir?

3. Eğitim düzeyleri değişkenine göre derslerde teknoloji kullanımına yönelik tutum ve teknolojiye karşı direnç puanları anlamlı farklılık göstermekte midir?

4. Uzaktan hayat bilgisi ve sosyal bilgiler öğretiminin niteliği değişkenine göre velilerin tutum ve direnç puanları anlamlı farklılık göstermekte midir?

5. Derslerde teknoloji kullanımına yönelik tutum ve teknolojiye karşı direnç puanları arasında bir ilişki var mıdır?

\section{YÖNTEM}

\section{Araştırma Deseni}

Araştırma, ilkokul düzeyindeki öğrenci velilerinin uzaktan hayat bilgisi ve sosyal bilgiler öğretimi sürecine yönelik görüşlerinin çeşitli değişkenler doğrultusunda belirlenmesine yönelik tarama modelinde tasarlanan bir nicel çalışmadır. Tarama modeli Karasar'ın (2004) da belirttiği gibi; "geçmişte ya da halen var olan bir durumu olduğu şekliyle betimlemeyi" amaçlamaktadır. $\mathrm{Bu}$ çalışmada da velilerin uzaktan hayat bilgisi ve sosyal bilgiler eğitimi sürecine yönelik görüşlerinin ve teknolojiye karşı dirençlerinin farklı değişkenlere incelenmesi amaçlandığından bu modele uygundur.

\section{Çalışma Grubu}

Araştırmada 2019-2020 eğitim-öğretim yılı bahar döneminde İstanbul ilinde ilkokul düzeyi 1, 2, 3 ve 4. sinıflarda öğrenim görmekte olan öğrencilerin velileri, amaçlı örnekleme yöntemi ile seçilmiştir. Seçilen veliler toplam 201 kişidir. Bunların 120'si anne ve 81'i babadır. Velilerin seçilmesinde, çocuklarının uzaktan eğitimde hayat bilgisi ve sosyal bilgiler dersini almakta olan kişiler olması amaçlanmıştır. Velilerin belirlenmesinin ardından çalışmaya katılma hususunda gönüllü olan kişilere, onam formu imzalatılmıştır. Çalışma için gerekli etik izin, İstanbul Üniversitesi-Cerrahpaşa Sosyal ve Beşeri Bilimler Etik Kurulu'ndan alınmıştır (08.03.2021 tarih ve 47991 sayılı Etik Kurul Başkanlığı Yazısı). Araştırma grubunun yüzdeliklerine yönelik özelliklere Tablo 1'de yer verilmiştir. 
Tablo 1.

Velilerin Cinsiyet ve Çocuklarının Sınıf Düzeyleri Değişkenlerine Göre Dağılımları

\begin{tabular}{ccccccc}
\hline \multirow{2}{*}{ Sinıf seviyesi } & \multicolumn{2}{c}{ Kadin } & \multicolumn{2}{c}{ Erkek } & \multicolumn{2}{c}{ Toplam } \\
\cline { 2 - 7 } & $\mathbf{n}$ & $\mathbf{0}$ & $\mathbf{n}$ & $\mathbf{0}$ & $\mathbf{n}$ & $\mathbf{0}$ \\
\hline 1. sinif & 31 & 15.42 & 21 & 10.45 & 52 & 25.87 \\
2. sinıf & 32 & 15.92 & 22 & 10.94 & 54 & 26.86 \\
3. sinıf & 26 & 12.94 & 10 & 4.97 & 36 & 17.91 \\
4. sinif & 31 & 15.43 & 28 & 13.93 & 59 & 29.36 \\
\hline Toplam & $\mathbf{1 2 0}$ & $\mathbf{5 9 . 7 1}$ & $\mathbf{8 1}$ & $\mathbf{4 0 . 2 9}$ & $\mathbf{2 0 1}$ & $\mathbf{1 0 0}$ \\
\hline
\end{tabular}

Tablo 1'de görüldüğü gibi, örneklemin 120'si kadın (\%59.71) ve 81'i erkekten (\%40.29) oluşmaktadır. Velilerin 52'sinin (\%25.87) çocukları 1. sınıfta, 54'ünün (\%26.86) 2. sinıfta, 36'sının (\%17.91) 3. sinifta ve 59'unun (29.36) 4. sinifta okumaktadir.

\section{Veri Toplama Araçları}

Velilerin teknoloji ve derslerde teknoloji kullanımına yönelik tutum ölçeği: Çalışmada kullanılan ve Kenar (2012) tarafından geliştirilen veri toplama aracı, 5’li Likert tipi bir ölçektir. Ölçekteki maddelerin 14'ü olumlu, 11'i olumsuz ifadeleri içermektedir. Açımlayıcı faktör analizi sonucunda ölçekte, toplam varyansın \% 55.85'ini açıklayan 14 olumlu, 11 olumsuz olmak üzere toplam 25 madde yer almıştır. Ölçeğin Cronbach's Alfa güvenirlik katsayısı .92' dir.

Teknolojiye karşı direnç ölçeği: Çalışmada kullanılan Özdemir ve Celayir'in (2020) geliştirdiği öğrenci velilerine yönelik teknolojiye karşı direnç ölçeğinde, uzman görüşü için 28 maddelik beşli likert tipi ölçek formu hazırlanmıştır. Olumlu ifadeler içeren maddeler ters kodlanmıştır. Ölçeğin güvenirliğini test etmek amacıyla Cronbach Alpha (iç tutarlılık) katsayısı hesaplanmış ve ölçekteki tüm maddelerin Cronbach Alpha katsayısı 0.85 bulunmuştur.

\section{Verilerin Analizi}

Araştırmacı, verilerin toplanması ve analiz sürecinde başlıca rolü oynamaktadır. Veriler, çalışmaya katılmakta gönüllü olan velilerden, araştırmacı tarafından toplanmıştır. Çevrim içi olarak toplanan ölçeklerin 11'inde eksik cevapların olması ve birden fazla seçeneğin işaretlenmesi gibi durumlar bulunmaktadır. Bu nedenle çalışma dışı tutulmuştur. Araştırmacı, toplanan ölçeklerden elde edilen verilerin analizlerinin yapılmasında SPSS programından yararlanmıştır.

Analizlere başlamadan önce verilerin normal dağılım gösterip göstermediğinin belirlenmesinde Kolmogorov-Smirnov testi yapılarak elde edilen puanların basıklık ve çarpıklık değerlerine bakılmıştır. Kolmogorov-Smirnov testine göre anlamlılık değeri .05 ten küçük çıkmıştır. Ayrıca çarpıklık ile basıklık [çarpıklık (0.50) ve basıklık (-0.90)] katsayısı, +2.00 ile -2.00 
arasında olduğu için verilerin normal dağılım gösterdiği söylenebilmektedir (George ve Mallery, 2010). Bu doğrultuda veri analizinde parametrik testler kullanılmıştır.

$\mathrm{Bu}$ parametrik testler, cinsiyet değişkeni için bağımsız örneklem $\mathrm{t}$ testi, eğitim düzeyleri, hayat bilgisi ve sosyal bilgiler derslerinin niteliği değişkenleri için Tek Yönlü Varyans Analizi (ANOVA) ve bağımlı değişkenler arasındaki ilişkinin ortaya konulması için ise, Pearson Çarpım Korelasyon Katsayısı tekniği olarak belirlenmiştir. Varyans Analizinde hangi gruplar arasında fark olduğunun belirlenmesinde Tukey-HSD testi uygulanmıştır. Bütün analizler .05 anlamlılık düzeyinde değerlendirilmiştir.

\section{BULGULAR}

\section{Velilerin Derslerde Teknoloji Kullanımına Yönelik Tutumları ve Teknolojiye Karşı}

\section{Dirençleri}

Velilerin derslerde teknoloji kullanımına yönelik tutum ve teknolojiye karşı direnç puanlarına ilişkin bulgulara Tablo 2 ve 3 'te yer verilmiştir.

Tablo 2.

Velilerin Derslerde Teknoloji Kullanımına Yönelik Tutumun Alt Boyutlarına İlişkin Puanları

\begin{tabular}{lccc}
\hline Ölçek boyutları & $\mathbf{N}$ & $\overline{\mathbf{X}}$ & $\mathbf{S}$ \\
\hline $\begin{array}{l}\text { Boyut 1- Teknoloji ve kullanımının öğrencinin sosyo-psikolojik gelişimindeki } \\
\text { Önemi ve rolü }\end{array}$ & 201 & 2.98 & 0.49 \\
$\begin{array}{l}\text { Boyut 2- Teknoloji ve kullanımının öğrencilerin derse ilgisine ve başarı } \\
\text { düzeylerine etkileri }\end{array}$ & 201 & 3.81 & 0.69 \\
Boyut 3- Dersin içsel ve dışsal niteliğine teknoloji etkileri & & & \\
Boyut 4- Teknoloji kullanımının öğrencilerin konuyu kendi hızlarına göre & 201 & 4.14 & 0.61 \\
öğrenmesine ve derse katılma düzeylerine etkileri & & & 0.86 \\
\hline Ölçek toplam & $\mathbf{2 0 1}$ & $\mathbf{3 . 6 7}$ & $\mathbf{0 . 4 6}$ \\
\hline
\end{tabular}

Ölçekte yer alan maddelerin 11'i birinci boyutta, 7'si ikinci boyutta, 4'üü üçüncü boyutta ve 3'ü dördüncü boyutta toplanmıştır. “Ölçek, 1'den 5'e kadar olan derecelendirme ölçeği olup her seçeneğe karşılık gelen puan aralıkları, kesinlikle katılıyorum (4.20-5.00), katılıyorum (3.40-4.19), orta derecede katıliyorum (2.60-3.39), katılmıyorum (1.80-2.59) ve kesinlikle katılmiyorum (1.001.79) şeklinde yorumlanmaktadır. Toplamda 2.59 ya da altında puan alınması olumsuz tutum, üzerinde puan alınması olumlu tutum olarak değerlendirilmektedir." (Kenar, 2012).

Tablo 2' de görüldüğüu üzere, veliler ‘Teknoloji ve kullanımının öğrencinin sosyo-psikolojik gelişimindeki önemi ve rolü’ ve ‘Teknoloji kullanımının öğrencilerin konuyu kendi hızlarına göre öğrenmesine ve derse katılma düzeylerine etkileri' boyutlarında orta düzeyde; 'Teknoloji ve kullanımının öğrencilerin derse ilgisine ve başarı düzeylerine etkileri' ve 'Dersin içsel ve dışsal niteliğine teknoloji etkileri' boyutlarından ise yüksek seviyede puanlar aldıkları göruilmektedir. Ölçeğin geneline göre bakmak gerekirse, velilerin derslerde teknoloji kullanımına yönelik tutumlarının olumlu düzeyde olduğu söylenebilir. 
Tablo 3.

Velilerin Teknolojiye Karşı Direnç Puan Ortalamaları

\begin{tabular}{lccc}
\hline Ölçek boyutları & $\mathbf{N}$ & $\overline{\mathbf{X}}$ & Ss \\
\hline Boyut 1- Teknolojik aletlere yönelik olumsuz tutum & 201 & 3.36 & 1.17 \\
Boyut 2- Teknolojik aletleri gereksiz görme & 201 & 2.50 & 1.00 \\
Boyut 3- Teknolojik aletlerin kullanımının zevk vermemesi & 201 & 2.26 & 1.06 \\
Boyut 4- Teknolojik aletlerin kullanımının zorluğu & 201 & 2.14 & 1.19 \\
Boyut 5- Teknolojik aletlere yönelik çevrenin olumsuz tutumu & 201 & 3.31 & 1.06 \\
Boyut 6- Teknolojik aletlere yönelik öz yetersizlik & 201 & 2.47 & 1.15 \\
Boyut 7- Teknolojik aletlere yönelik algilanan kullanışsızlık & 201 & 2.67 & 1.23 \\
\hline Ölçek toplam & $\mathbf{2 0 1}$ & $\mathbf{2 . 6 7}$ & $\mathbf{0 . 6 5}$ \\
\hline
\end{tabular}

Tablo 3'te yer alan Direnç Ölçeği'nde yer alan maddelerin 7'si birinci boyutta, 7'si ikinci boyutta, 3'ü üçüncü boyutta, 3'ü dördüncü boyutta, 3'ü beşinci boyutta, 3'ü altıncı boyutta ve 2'si yedinci boyutta toplanmıştır. Formdaki maddelere verilen yanıtlar, direnç durumlarını yansıtan ifadeler için "kesinlikle katılıyorum" 5 puan, "kesinlikle katılmıyorum” 1 puan olacak şekilde puanlanmıştır.

Velilerin Tablo 3'teki veriler doğrultusunda; 1., 5. ve 7. boyutlarda orta düzeyde direnç gösterdikleri, 2., 3., 4., ve 6. boyutlarda direnç düzeyinin düşük düzeyde olduğu görülmektedir. Ölçeğin genelinde ise, velilerin teknolojiye yönelik gösterdikleri direnç orta düzeydedir.

Cinsiyet Değişkenine Göre Derslerde Teknoloji Kullanımına Yönelik Tutum ve Teknolojiye Karşı Direnç Puanları

Velilerin teknolojiye yönelik tutum ve teknolojiye karşı direnç puan ortalamalarının cinsiyet değişkenine göre anlamlı farklılık gösterip göstermediğine ilişkin bağımsız grup t testi sonuçlarına Tablo 4 ve 5'te yer verilmiştir.

Tablo 4.

Cinsiyet Değişkenine Göre “Derslerde Teknoloji Kullanımına Yönelik Tutum Ölçeği” Puanlarının Bağımsız Örneklem t Testi Sonuçları

\begin{tabular}{|c|c|c|c|c|c|c|c|}
\hline Boyutlar & Cinsiyet & $\mathbf{N}$ & $\overline{\mathbf{X}}$ & sd & Ss & $\mathbf{t}$ & p \\
\hline \multirow{2}{*}{ Boyut 1} & Kadın & 120 & 2.98 & 199 & .51 & \multirow{2}{*}{0.035} & \multirow{2}{*}{.972} \\
\hline & Erkek & 81 & 2.98 & & .45 & & \\
\hline \multirow{2}{*}{ Boyut 2} & Kadın & 120 & 3.91 & 199 & .68 & \multirow{2}{*}{1.792} & \multirow{2}{*}{.076} \\
\hline & Erkek & 81 & 3.66 & & .69 & & \\
\hline \multirow{2}{*}{ Boyut 3} & Kadın & 120 & 4.20 & 199 & .60 & \multirow{2}{*}{1.050} & \multirow{2}{*}{.296} \\
\hline & Erkek & 81 & 4.06 & & .63 & & \\
\hline \multirow{2}{*}{ Boyut 4} & Kadın & 120 & 3.82 & 199 & .87 & \multirow{2}{*}{1.276} & \multirow{2}{*}{.302} \\
\hline & Erkek & 81 & 3.60 & & .85 & & \\
\hline \multirow{2}{*}{ Toplam } & Kadın & 120 & 3.73 & 199 & .45 & \multirow{2}{*}{1.615} & \multirow{2}{*}{.110} \\
\hline & Erkek & 81 & 3.58 & & .46 & & \\
\hline
\end{tabular}
${ }^{*} p<.05$

Cinsiyet değişkeni ile “Derslerde Teknoloji Kullanımına Yönelik Tutum” Ölçeği ‘Birinci boyut: Teknoloji ve kullanımının öğrencinin sosyo-psikolojik gelişimindeki önemi ve rolü' (t=- 
.035, p>.05), 'Íkinci boyut: Teknoloji ve kullanımının öğrencilerin derse ilgisine ve başarı düzeylerine etkileri' ( $\mathrm{t}=-1.792$, p>.05), 'Üçüncü boyut: Dersin içsel ve dışsal niteliğine teknoloji

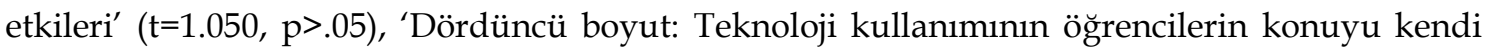
hızlarına göre öğrenmesine ve derse katılma düzeylerine etkileri' ( $t=1.276, p>.05)$, boyutları ve ölçek toplam puan ortalamaları ( $\mathrm{t}=1.615, \mathrm{p}>.05)$ arasında anlamlı bir farklılığa rastlanmamıştır. Ancak, kadın ve erkeklerin aldıkları puanlara göre yorum yapmak gerekirse; kadınların ortalama tutum puanlarının erkeklere oranla daha yuiksek olduğu görülmektedir.

Tablo 5.

Cinsiyet Değişkenine Göre “Teknolojiye Karşı Direnç Ölçeği” Puanlarının Bağımsız Örneklem t Testi Sonuçları

\begin{tabular}{|c|c|c|c|c|c|c|c|}
\hline Boyutlar & Cinsiyet & $\mathbf{N}$ & $\overline{\mathbf{X}}$ & sd & Ss & $\mathbf{t}$ & $\mathbf{p}$ \\
\hline \multirow{2}{*}{ Boyut 1} & Kadin & 120 & 3.40 & 199 & 1.17 & .403 & .68 \\
\hline & Erkek & 81 & 3.30 & & 1.18 & & \\
\hline \multirow{2}{*}{ Boyut 2} & Kadın & 120 & 2.53 & 199 & 1.08 & .467 & .64 \\
\hline & Erkek & 81 & 2.44 & & .87 & & \\
\hline \multirow{2}{*}{ Boyut 3} & Kadın & 120 & 2.27 & 199 & 1.08 & .106 & .91 \\
\hline & Erkek & 81 & 2.25 & & 1.05 & & \\
\hline \multirow{2}{*}{ Boyut 4} & Kadın & 120 & 2.09 & 199 & 1.15 & -.539 & .59 \\
\hline & Erkek & 81 & 2.22 & & 1.27 & & \\
\hline \multirow{2}{*}{ Boyut 5} & Kadın & 120 & 3.24 & 199 & 1.06 & -.750 & .45 \\
\hline & Erkek & 81 & 3.40 & & 1.05 & & \\
\hline \multirow{2}{*}{ Boyut 6} & Kadın & 120 & 2.49 & 199 & 1.11 & .213 & .83 \\
\hline & Erkek & 81 & 2.44 & & 1.21 & & \\
\hline \multirow{2}{*}{ Boyut 7} & Kadın & 120 & 2.68 & 199 & 1.26 & .021 & .98 \\
\hline & Erkek & 81 & 2.67 & & 1.20 & & \\
\hline \multirow{2}{*}{ Toplam } & Kadın & 120 & 2.67 & 199 & .66 & -.025 & .98 \\
\hline & Erkek & 81 & 2.67 & & .65 & & \\
\hline
\end{tabular}

Cinsiyet değişkeni ile “Teknolojiye Karşı Direnç Ölçeği”, ,'Birinci boyut: Teknolojik aletlere yönelik olumsuz tutum' ( $\mathrm{t}=.403, \mathrm{p}>.05)$, 'İkinci boyut: Teknolojik aletleri gereksiz görme' ( $\mathrm{t}=.467, \mathrm{p}>.05)$, 'Üçüncü boyut: Teknolojik aletlerin kullanımının zevk vermemesi' $(\mathrm{t}=.106$, p>.05), 'Dördüncü boyut: Teknolojik aletlerin kullanımının zorluğu' ( $t=-.539, p>.05)$, 'Beşinci boyut: Teknolojik aletlere yönelik çevrenin olumsuz tutumu' ( $\mathrm{t}=-.750, \mathrm{p}>.05)$ 'Altıncı boyut: Teknolojik aletlere yönelik öz yetersizlik' ( $t=.213, p>.05)$, 'Yedinci boyut: Teknolojik aletlere yönelik algılanan kullanışsızlık' $(t=.021, p>.05)$, boyutları ve ölçek toplam puan ortalamaları $(t=-$ $.025, \mathrm{p}>.05$ ) arasında anlamlı bir farklılığa rastlanmamıştır. Ancak, kadın ve erkeklerin aldıkları puanlara göre yorum yapmak gerekirse; kadınların teknolojiye karşı direnç puan ortalamalarının erkeklerinkiyle eşit olduğu görülmektedir.

Eğitim Düzeyi Değişkenine Göre Derslerde Teknoloji Kullanımına Yönelik Tutum ve Teknolojiye Karşı Direnç Puanları 
Velilerin teknolojiye yönelik tutum ve teknolojiye karşı direnç puan ortalamalarının eğitim düzeyleri değişkenine göre anlamlı farklılık gösterip göstermediğine ilişkin Tek Yönlü Varyans Analizi (ANOVA) testi sonuçlarına Tablo 6 ve 7' de yer verilmiştir.

Tablo 6.

Eğitim Düzeyi Değişkenine Göre Derslerde Teknoloji Kullanımına Yönelik Tutum Ölçeği Puanlarının Tek Yönlü Varyans Analizi Sonuçları

\begin{tabular}{|c|c|c|c|c|c|c|c|c|c|}
\hline Boyutlar & Grup & $\mathbf{N}$ & $\overline{\mathbf{X}}$ & ss & Var. K. & KT & KO & $\mathbf{F}$ & p \\
\hline \multirow{5}{*}{ Boyut 1} & İlkokul & 41 & 3.34 & .58 & G. Aras1 & 2.925 & .975 & 4.476 & $.005^{*}$ \\
\hline & Ortaokul & 43 & 3.06 & .42 & G. İçi & 21.131 & .218 & & \\
\hline & Lise & 61 & 2.88 & .45 & Toplam & 24.056 & & & \\
\hline & Üniversite & 56 & 2.87 & .43 & & & & & \\
\hline & Toplam & 201 & 2.98 & .49 & & & & & \\
\hline \multirow{5}{*}{ Boyut 2} & İlkokul & 41 & 3.40 & .46 & G. Arası & 5.704 & 1.901 & 4.301 & $.007^{*}$ \\
\hline & Ortaokul & 43 & 3.72 & .77 & G. İçi & 4.881 & .442 & & \\
\hline & Lise & 61 & 3.78 & .68 & Toplam & 48.585 & & & \\
\hline & Üniversite & 56 & 4.11 & .66 & & & & & \\
\hline & Toplam & 201 & 3.81 & .69 & & & & & \\
\hline \multirow{5}{*}{ Boyut 3} & İlkokul & 41 & 4.23 & .44 & G. Arası & 1.312 & .437 & 1.148 & .334 \\
\hline & Ortaokul & 43 & 3.91 & .64 & G. İçi & 36.960 & .381 & & \\
\hline & Lise & 61 & 4.15 & .68 & Toplam & 38.272 & & & \\
\hline & Üniversite & 56 & 4.23 & .59 & & & & & \\
\hline & Toplam & 201 & 4.14 & .61 & & & & & \\
\hline \multirow{5}{*}{ Boyut 4} & İlkokul & 41 & 3.43 & .94 & G. Aras1 & 7.295 & 2.432 & 3.452 & $.020^{*}$ \\
\hline & Ortaokul & 43 & 3.48 & .96 & G. İçi & 68.331 & .704 & & \\
\hline & Lise & 61 & 3.66 & .82 & Toplam & 75.626 & & & \\
\hline & Üniversite & 56 & 4.11 & .72 & & & & & \\
\hline & Toplam & 201 & 3.73 & .86 & & & & & \\
\hline \multirow{5}{*}{ Toplam } & İlkokul & 41 & 3.60 & .49 & G. Arası & 1.290 & .430 & 2.060 & .111 \\
\hline & Ortaokul & 43 & 3.54 & .54 & G. İçi & 20.252 & .209 & & \\
\hline & Lise & 61 & 3.62 & .44 & Toplam & 21.542 & & & \\
\hline & Üniversite & 56 & 3.83 & .38 & & & & & \\
\hline & Toplam & 201 & 3.67 & .46 & & & & & \\
\hline
\end{tabular}

Tablo 6'da görüldüğü üzere, "Derslerde Teknoloji Kullanımına Yönelik Tutum Ölçeği”, ‘Birinci boyut: Teknoloji ve kullanımının öğrencinin sosyo-psikolojik gelişimindeki önemi ve rolü' ( $\mathrm{F}=4.476, \mathrm{p}<.05)$, 'İkinci boyut: Teknoloji ve kullanımının öğrencilerin derse ilgisine ve başarı düzeylerine etkileri' $(\mathrm{F}=4.301, \mathrm{p}<.05)$ ve 'Dördüncü boyut: Teknoloji kullanımının öğrencilerin konuyu kendi hızlarına göre öğrenmesine ve derse katılma düzeylerine etkileri' $(\mathrm{F}=3.452, \mathrm{p}<.05)$ boyutları arasında istatistiksel olarak anlamlı bir fark bulunmaktadır.

Farkın hangi gruplar arasında olduğunu belirlemek için Post-hoc Tukey HSD testi yapılmıştır. Buna göre; 1. boyutta, ilkokuldan mezun olan velilerin puan ortalamaları, lise ve üniversiteden mezun olan velilerinkilere göre anlamlı düzeyde yüksektir. 2. boyut ve 4 . boyutta ise, ilkokuldan mezun olan velilerin puan ortalamaları, üniversiteden mezun olan velilerinkilere 
göre anlamlı düzeyde yüksektir. Buradan anlaşıldığı üzere; eğitim düzeyinin artışılla velilerin derslerde teknoloji kullanımına yönelik tutumları ters orantılı olarak azalma göstermektedir.

Ayrıca 'Üçüncü boyut: Dersin içsel ve dışsal niteliğine teknoloji etkileri' ( $F=1.148, p>.05)$, boyutu ve ölçek toplam puan $(\mathrm{F}=2.060, \mathrm{p}>.05)$ ortalamaları arasında anlamlı bir farklılığa rastlanmamıştır.

Tablo 7.

Eğitim Düzeyi Değişkenine Göre “Teknolojiye Karşı Direnç Ölçeği” Puanlarının Tek Yönlü Varyans Analizi Sonuçları

\begin{tabular}{|c|c|c|c|c|c|c|c|c|c|}
\hline Boyutlar & Gruplar & $\mathbf{N}$ & $\overline{\mathbf{X}}$ & ss & Var. K. & KT & $\mathrm{KO}$ & $\mathbf{F}$ & $p$ \\
\hline \multirow{5}{*}{ Boyut 1} & İlkokul & 41 & 3.81 & 1.01 & G. aras1 & 6.752 & 2.251 & 1.660 & .181 \\
\hline & Ortaokul & 43 & 3.14 & 1.22 & G. içi & 131.516 & 1.356 & & \\
\hline & Lise & 61 & 3.49 & 1.13 & Toplam & 138.268 & & & \\
\hline & Üniversite & 56 & 3.10 & 1.22 & & & & & \\
\hline & Toplam & 201 & 3.36 & 1.17 & & & & & \\
\hline \multirow{5}{*}{ Boyut 2} & İlkokul & 41 & 3.08 & .95 & G. aras1 & 11.304 & 3.768 & 4.080 & $.009^{*}$ \\
\hline & Ortaokul & 43 & 2.84 & .93 & G. içi & 89.579 & .923 & & \\
\hline & Lise & 61 & 2.29 & .92 & Toplam & 100.883 & & & \\
\hline & Üniversite & 56 & 2.23 & 1.01 & & & & & \\
\hline & Toplam & 201 & 2.50 & 1.00 & & & & & \\
\hline \multirow{5}{*}{ Boyut 3} & İlkokul & 41 & 2.91 & 1.02 & G. aras1 & 8.535 & 2.845 & 2.620 & .055 \\
\hline & Ortaokul & 43 & 2.27 & .92 & G. içi & 105.313 & 1.086 & & \\
\hline & Lise & 61 & 2.09 & 1.06 & Toplam & 113.848 & & & \\
\hline & Üniversite & 56 & 2.11 & 1.08 & & & & & \\
\hline & Toplam & 201 & 2.26 & 1.06 & & & & & \\
\hline \multirow{5}{*}{ Boyut 4} & İlkokul & 41 & 2.81 & 1.28 & G. aras1 & 12.211 & 4.070 & 2.999 & $.034^{*}$ \\
\hline & Ortaokul & 43 & 2.33 & 1.37 & G. içi & 131.659 & 1.357 & & \\
\hline & Lise & 61 & 2.07 & 1.13 & Toplam & 143.870 & & & \\
\hline & Üniversite & 56 & 1.77 & .99 & & & & & \\
\hline & Toplam & 201 & 2.14 & 1.19 & & & & & \\
\hline \multirow{5}{*}{ Boyut 5} & İlkokul & 41 & 3.16 & 1.11 & G. aras1 & .867 & .289 & .251 & .861 \\
\hline & Ortaokul & 43 & 3.48 & 1.06 & G. içi & 111.857 & 1.153 & & \\
\hline & Lise & 61 & 3.29 & 1.03 & Toplam & 112.724 & & & \\
\hline & Üniversite & 56 & 3.30 & 1.10 & & & & & \\
\hline & Toplam & 201 & 3.31 & 1.06 & & & & & \\
\hline \multirow{5}{*}{ Boyut 6} & İlkokul & 41 & 3.00 & 1.18 & G. aras1 & 9.576 & 3.192 & 2.523 & .062 \\
\hline & Ortaokul & 43 & 2.31 & 1.06 & G. içi & 122.705 & 1.265 & & \\
\hline & Lise & 61 & 2.62 & 1.21 & Toplam & 132.282 & & & \\
\hline & Üniversite & 56 & 2.11 & 1.01 & & & & & \\
\hline & Toplam & 201 & 2.47 & 1.15 & & & & & \\
\hline \multirow{5}{*}{ Boyut 7} & İlkokul & 41 & 2.93 & 1.25 & G. aras1 & 4.928 & 1.643 & 1.078 & .362 \\
\hline & Ortaokul & 43 & 3.00 & 1.12 & G. içi & 147.864 & 1.524 & & \\
\hline & Lise & 61 & 2.61 & 1.39 & Toplam & 152.792 & & & \\
\hline & Üniversite & 56 & 2.43 & 1.07 & & & & & \\
\hline & Toplam & 201 & 2.67 & 1.23 & & & & & \\
\hline \multirow{5}{*}{ Toplam } & İlkokul & 41 & 3.10 & .65 & G. aras1 & 4.859 & 1.620 & 4.063 & $.009^{*}$ \\
\hline & Ortaokul & 43 & 2.77 & .57 & G. içi & 38.665 & .399 & & \\
\hline & Lise & 61 & 2.64 & .65 & Toplam & 43.524 & & & \\
\hline & Üniversite & 56 & 2.44 & .61 & & & & & \\
\hline & Toplam & 201 & 2.67 & .65 & & & & & \\
\hline
\end{tabular}


Tablo 7'de görüldüğüü üzere, "Teknolojiye Karşı Direnç Ölçeği”, 'İkinci boyut: Teknolojik aletleri gereksiz görme' ( $F=4.080, p<.05)$, ‘Dördüncü boyut: Teknoloji kullanımının öğrencilerin konuyu kendi hızlarına göre öğrenmesine ve derse katılma düzeylerine etkileri' $(F=2.999, p<.05)$ ve ölçek toplam puan $(\mathrm{F}=4.063, \mathrm{p}<.05)$ ortalamaları arasında istatistiksel olarak anlamlı bir fark bulunmaktadir.

Farkın hangi gruplar arasında olduğunu belirlemek için Post-hoc Tukey HSD testi yapılmıştır. Buna göre; 'Teknolojik aletleri gereksiz görme' boyutunda (2. boyut), ilkokuldan mezun olan velilerin puan ortalamaları, lise ve üniversiteden mezun olan velilerinkilere göre anlamlı düzeyde yüksektir. Teknoloji kullanımının öğrencilerin konuyu kendi hızlarına göre öğrenmesine ve derse katılma düzeylerine etkileri boyutunda (4. boyut) ve ölçeğin toplamında ilkokuldan mezun olan velilerin puan ortalamaları, üniversiteden mezun olan velilerinkilere göre anlamlı düzeyde yüksektir. Bu durum, velilerin teknolojiye karşı dirençlerinin, eğitim düzeyinin artmasıyla ters orantılı olduğunu göstermektedir.

Ayrıca, 'Birinci boyut: Teknolojik aletlere yönelik olumsuz tutum' ( $F=1.660, p>.05)$, 'Üçüncü boyut: Dersin içsel ve dişsal niteliğine teknoloji etkileri' ( $F=2.620, p>.05)$, 'Beşinci boyut: Teknolojik aletlere yönelik çevrenin olumsuz tutumu' $(\mathrm{F}=.251, \mathrm{p}>.05)$, 'Altıncı boyut: Teknolojik aletlere yönelik öz yetersizlik' ( $\mathrm{F}=2.523, \mathrm{p}>.05)$, 'Yedinci boyut: Teknolojik aletlere yönelik algılanan kullanışsızlık' ( $\mathrm{F}=1.078, \mathrm{p}>.05)$ boyutları ortalamaları arasında anlamlı bir farklılığa rastlanmamıştır.

\section{Uzaktan Hayat Bilgisi ve Sosyal Bilgiler Öğretiminin Niteliği Değişkenine Göre} Velilerin Tutum ve Direnç Puanları Arasındaki Ilişki

Velilerin derslerde teknolojiye yönelik tutum ve teknolojiye karşı direnç puan ortalamalarının uzaktan verilen derslerde hayat bilgisi ve sosyal bilgiler öğretiminin nitelikli olup olmadığı değişkenine göre anlamlı farklılık gösterip göstermediğine ilişkin Tek Yönlü Varyans Analizi (ANOVA) testi sonuçlarına Tablo 8 ve 9' da yer verilmiştir.

Tablo 8.

Uzaktan Hayat Bilgisi ve Sosyal Bilgiler Öğretiminin Niteliği Değişkenine Göre “Derslerde Teknoloji Kullanımına Yönelik Tutum Ölçeği" Puanlarının Tek Yönlü Varyans Analizi Sonuçları

\begin{tabular}{|c|c|c|c|c|c|c|c|c|c|}
\hline Boyutlar & Gruplar & $\mathbf{N}$ & $\overline{\mathbf{X}}$ & ss & Var. K. & KT & $\mathrm{KO}$ & $\mathbf{F}$ & $p$ \\
\hline \multirow{4}{*}{ Boyut 1} & Niteliksiz & 46 & 3.06 & .66 & G. aras 1 & 1.580 & .790 & 3.445 & .036 \\
\hline & $\begin{array}{l}\text { Kismen } \\
\text { Nitelikli }\end{array}$ & 72 & 3.12 & .52 & G. içi & 22.476 & .229 & & \\
\hline & Nitelikli & 83 & 2.85 & .37 & Toplam & 24.056 & & & \\
\hline & Toplam & 201 & 2.98 & .49 & & & & & \\
\hline \multirow{4}{*}{ Boyut 2} & Niteliksiz & 46 & 4.03 & .60 & G. aras 1 & 1.043 & .521 & 1.075 & .345 \\
\hline & $\begin{array}{l}\text { Kismen } \\
\text { Nitelikli }\end{array}$ & 72 & 3.71 & .68 & G. içi & 47.542 & .485 & & \\
\hline & Nitelikli & 83 & 3.83 & .72 & Toplam & 48.585 & & & \\
\hline & Toplam & 201 & 3.81 & .69 & & & & & \\
\hline
\end{tabular}


Tablo 8 (Devam)

\begin{tabular}{|c|c|c|c|c|c|c|c|c|c|}
\hline \multirow{4}{*}{ Boyut 3} & Niteliksiz & 46 & 4.11 & .52 & G. aras1 & .090 & .045 & 1.019 & .365 \\
\hline & $\begin{array}{l}\text { Kismen } \\
\text { Nitelikli }\end{array}$ & 72 & 4.18 & .72 & G. içi & 38.182 & .390 & & \\
\hline & Nitelikli & 83 & 4.12 & .56 & Toplam & 38.272 & & & \\
\hline & Toplam & 201 & 4.14 & .61 & & & & & \\
\hline \multirow{4}{*}{ Boyut 4} & Niteliksiz & 46 & 4.05 & .71 & G. arası & 1.540 & .770 & .116 & .891 \\
\hline & $\begin{array}{l}\text { Kismen } \\
\text { Nitelikli }\end{array}$ & 72 & 3.71 & .87 & G. içi & 74.085 & .756 & & \\
\hline & Nitelikli & 83 & 3.66 & .89 & Toplam & 75.626 & & & \\
\hline & Toplam & 201 & 3.73 & .86 & & & & & \\
\hline \multirow{4}{*}{ Toplam } & Niteliksiz & 46 & 3.81 & .41 & G. arası & .391 & .196 & .906 & .407 \\
\hline & $\begin{array}{l}\text { Kismen } \\
\text { Nitelikli }\end{array}$ & 72 & 3.68 & .48 & G. içi & 21.151 & .216 & & \\
\hline & Nitelikli & 83 & 3.62 & .45 & Toplam & 21.542 & & & \\
\hline & Toplam & 201 & 3.67 & .46 & & & & & \\
\hline
\end{tabular}

${ }^{*} \mathrm{p}<.05$

Tablo 8'de görüldüğü üzere, 201 veliden 46'sı dişındaki veliler, hayat bilgisi ve sosyal bilgiler derslerinin uzaktan eğitimle işlenmesinin kısmen nitelikli veya nitelikli olduğunu düşünmektedir. İstatistiksel olarak bakıldığında, “Derslerde Teknoloji Kullanımına Yönelik Tutum Ölçeği”, 'Birinci boyut: Teknoloji ve kullanımının öğrencinin sosyo-psikolojik gelişimindeki önemi ve rolü' $(\mathrm{F}=3.445, \mathrm{p}<.05)$ boyutu ortalamaları arasında anlamlı bir fark bulunmaktadir.

Farkın hangi gruplar arasında olduğunu belirlemek için Post-hoc Tukey HSD testi yapılmıştır. Buna göre; Birinci boyut olan ‘Teknoloji ve kullanımının öğrencinin sosyo-psikolojik gelişimindeki önemi ve rolü' boyutunda; uzaktan hayat bilgisi ve sosyal bilgiler öğretiminin "kısmen nitelikli" olduğunu söyleyenlerin puan ortalamaları, "nitelikli" olduğunu söyleyen velilerinkilere göre anlamlı düzeyde yüksektir.

Ayrıca, ikinci boyut (F=1.075, p>.05), üçüncü boyut $(F=1.019, p>.05)$, dördüncü boyut $(\mathrm{F}=.116, \mathrm{p}>.05)$ ve ölçek toplam puan $(\mathrm{F}=.906, \mathrm{p}>.05)$ ortalamaları arasında uzaktan hayat bilgisi ve sosyal bilgiler öğretiminin niteliği değişkenine göre anlamlı bir farklılığa rastlanmamıştır.

Tablo 9 .

Uzaktan Hayat Bilgisi Ve Sosyal Bilgiler Öğretiminin Niteliği Değişkenine Göre “Teknolojiye Karşı Direnç Ölçeği” Puanlarının Tek Yönlü Varyans Analizi Sonuçları

\begin{tabular}{|c|c|c|c|c|c|c|c|c|c|}
\hline Boyutlar & Gruplar & $\mathbf{N}$ & $\overline{\mathbf{X}}$ & ss & Var. K. & KT & KO & $\mathbf{F}$ & $\mathrm{p}$ \\
\hline \multirow{4}{*}{ Boyut 1} & Niteliksiz & 46 & 3.38 & 1.39 & G. aras 1 & .250 & .125 & .089 & .915 \\
\hline & $\begin{array}{l}\text { Kismen } \\
\text { Nitelikli }\end{array}$ & 72 & 3.41 & 1.13 & G. içi & 138.018 & 1.408 & & \\
\hline & Nitelikli & 83 & 3.31 & 1.16 & Toplam & 138.268 & & & \\
\hline & Toplam & 201 & 3.36 & 1.17 & & & & & \\
\hline \multirow{4}{*}{ Boyut 2} & Niteliksiz & 46 & 2.80 & 1.08 & G. aras 1 & 1.440 & .720 & .710 & .494 \\
\hline & $\begin{array}{l}\text { Kismen } \\
\text { Nitelikli }\end{array}$ & 72 & 2.49 & 1.01 & G. içi & 99.442 & 1.015 & & \\
\hline & Nitelikli & 83 & 2.42 & .97 & Toplam & 100.883 & & & \\
\hline & Toplam & 201 & 2.50 & 1.00 & & & & & \\
\hline
\end{tabular}


Tablo 9 (Devam)

\begin{tabular}{|c|c|c|c|c|c|c|c|c|c|}
\hline \multirow{4}{*}{ Boyut 3} & Niteliksiz & 46 & 2.41 & 1.11 & G. aras1 & .355 & .177 & .153 & .858 \\
\hline & $\begin{array}{l}\text { Kismen } \\
\text { Nitelikli }\end{array}$ & 72 & 2.26 & 1.04 & G. içi & 113.494 & 1.158 & & \\
\hline & Nitelikli & 83 & 2.22 & 1.09 & Toplam & 113.848 & & & \\
\hline & Toplam & 201 & 2.26 & 1.06 & & & & & \\
\hline \multirow{4}{*}{ Boyut 4} & Niteliksiz & 46 & 1.94 & 1.21 & G. aras1 & 3.429 & 1.715 & 1.196 & .307 \\
\hline & $\begin{array}{l}\text { Kismen } \\
\text { Nitelikli }\end{array}$ & 72 & 2.37 & 1.18 & G. içi & 140.441 & 1.433 & & \\
\hline & Nitelikli & 83 & 2.01 & 1.20 & Toplam & 143.870 & & & \\
\hline & Toplam & 201 & 2.14 & 1.19 & & & & & \\
\hline \multirow{4}{*}{ Boyut 5} & Niteliksiz & 46 & 3.10 & 1.11 & G. aras1 & .647 & .324 & .283 & .754 \\
\hline & $\begin{array}{l}\text { Kismen } \\
\text { Nitelikli }\end{array}$ & 72 & 3.33 & 1.06 & G. içi & 112.076 & 1.144 & & \\
\hline & Nitelikli & 83 & 3.34 & 1.06 & Toplam & 112.724 & & & \\
\hline & Toplam & 201 & 3.31 & 1.06 & & & & & \\
\hline \multirow{4}{*}{ Boyut 6} & Niteliksiz & 46 & 2.61 & 1.07 & G. aras1 & 2.620 & 1.310 & .990 & .375 \\
\hline & $\begin{array}{l}\text { Kısmen } \\
\text { Nitelikli }\end{array}$ & 72 & 2.63 & 1.12 & G. içi & 129.662 & 1.323 & & \\
\hline & Nitelikli & 83 & 2.30 & 1.18 & Toplam & 132.282 & & & \\
\hline & Toplam & 201 & 2.47 & 1.15 & & & & & \\
\hline \multirow{4}{*}{ Boyut 7} & Niteliksiz & 46 & 2.92 & 1.36 & G. aras1 & 1.072 & .536 & .346 & .708 \\
\hline & $\begin{array}{l}\text { Kısmen } \\
\text { Nitelikli }\end{array}$ & 72 & 2.69 & 1.13 & G. içi & 151.721 & 1.548 & & \\
\hline & Nitelikli & 83 & 2.60 & 1.29 & Toplam & 152.792 & & & \\
\hline & Toplam & 201 & 2.67 & 1.23 & & & & & \\
\hline \multirow{4}{*}{ Toplam } & Niteliksiz & 46 & 2.74 & .80 & G. arası & .483 & .242 & .550 & .579 \\
\hline & $\begin{array}{c}\text { Kismen } \\
\text { Nitelikli }\end{array}$ & 72 & 2.74 & .66 & G. içi & 43.041 & .439 & & \\
\hline & Nitelikli & 83 & 2.60 & .62 & Toplam & 43.524 & & & \\
\hline & Toplam & 201 & 2.67 & .65 & & & & & \\
\hline
\end{tabular}

${ }^{*} \mathrm{p}<.05$

Tablo 9'da görüldüğü üzere, “Teknolojiye Karşı Direnç Ölçeği”, tüm boyut ve ölçek toplam puan ortalamaları arasında anlamlı bir farklılığa rastlanmamıştır (p>.05). Ancak ölçeğin boyutlarındaki ve tüm ölçekteki puan ortalamaları karşılaştırıldığında; genel olarak derslerin "niteliksiz" geçtiğini söyleyen velilerle "kısmen nitelikli" geçtiğini söyleyen velilerin teknolojiye karşı direnç puanlarının daha yüksek olduğu görülmektedir (1. Boyutta, Kısmen Nitelikli: $x=3.41$; 2. Boyutta Niteliksiz: $x=2.80 ; 3$. Boyutta Niteliksiz: $x=2.41 ; 4$. Boyutta Kismen Nitelikli: $x=2.37 ; 6$. Boyutta Kısmen Nitelikli: $x=2.63$; 7 . Boyutta Niteliksiz: $x=2.92$; Ölçek Toplamda Niteliksiz: $x=2.74$ ve Kısmen Nitelikli: $x=2.74)$.

Buradan çıkarılan sonuç; velilerin teknolojiye karşı direnç göstermeleri, hayat bilgisi ve sosyal bilgiler derslerinin niteliksiz ya da kısmen nitelikli şekilde işlendiğini düşünmeleriyle ilgili olabilir.

\section{Derslerde Teknoloji Kullanımına Yönelik Tutum ve Teknolojiye Karşı Direnç Puanları}

Velilerin hayat bilgisi ve sosyal bilgiler derslerinde teknoloji kullanımına yönelik tutum puanları ve teknolojiye karşı direnç puanları arasında bir ilişki olup olmadığını belirlemek amacıyla Pearson Çarpım Moment Korelasyon Analizi yapılmıştır. Elde edilen verilere Tablo $10^{\prime}$ da yer verilmektedir. 
Tablo 10.

“Derslerde Teknoloji Kullanımına Yönelik Tutum” Puanları ile “Teknolojiye Karşı Direnç” Puanlarının Pearson Çarpım Moment Korelasyon Analizi Sonuçları

\begin{tabular}{lccc}
\hline Değişkenler & $\mathbf{N}$ & $\mathbf{r}$ & $\mathbf{p}$ \\
\hline $\begin{array}{l}\text { Teknolojiye Karş1 Direnç Ölçeği } \\
\text { Derslerde Teknoloji Kullanımına Yönelik Tutum Ölçeği 1. Boyut }\end{array}$ & 201 & .618 & $.000^{*}$ \\
\hline $\begin{array}{l}\text { Teknolojiye Karş1 Direnç Ölçeği } \\
\text { Derslerde Teknoloji Kullanımına Yönelik Tutum Ölçeği 2. Boyut }\end{array}$ & 201 & -.172 & .085 \\
\hline $\begin{array}{l}\text { Teknolojiye Karş1 Direnç Ölçeği } \\
\text { Derslerde Teknoloji Kullanımına Yönelik Tutum Ölçeği 3. Boyut }\end{array}$ & 201 & -.217 & $.029^{*}$ \\
\hline $\begin{array}{l}\text { Teknolojiye Karşı Direnç Ölçeği } \\
\text { Derslerde Teknoloji Kullanımına Yönelik Tutum Ölçeği 4. Boyut }\end{array}$ & 201 & -.188 & .060 \\
\hline${ }^{*} p<.05$ & &
\end{tabular}

Tablo 10'da görüldüğü üzere yapılan analiz sonucunda, velilerin “Teknolojiye Karş1 Direnç Ölçeği” toplam puanları ile ‘Derslerde Teknoloji Kullanımına Yönelik Tutum Ölçeği 1. Boyut' arasında $(\mathrm{r}=.618 ; \mathrm{p}<.01)$ orta düzeyde pozitif yönde ve ‘3. Boyut' arasında $(\mathrm{r}=-.217 ; \mathrm{p}<.05)$ çok zayıf düzeyde negatif yönde anlamlı bir ilişki tespit edilmiştir. Velilerin “Teknolojiye Karşı Direnç Ölçeği” toplam puanları ile 'Derslerde Teknoloji Kullanımına Yönelik Tutum Ölçeği 2. Boyut' arasında ( $\mathrm{r}=-172 ; \mathrm{p}>.04)$ çok zayıf düzeyde negatif yönde ve '4. Boyut' arasında (r=-.188; p>.05) çok zayıf düzeyde negatif yönde anlamlı olmayan bir ilişki tespit edilmiştir.

\section{TARTIŞMA}

$\mathrm{Bu}$ çalışmada elde edilen sonuçlara göre velilerin “Derslerde Teknoloji Kullanımına Yönelik Tutum Ölçeği”, ‘Teknoloji ve kullanımının öğrencinin sosyo-psikolojik gelişimindeki önemi ve rolü’ ve ‘Teknoloji kullanımının öğrencilerin konuyu kendi hızlarına göre öğrenmesine ve derse katılma düzeylerine etkileri' boyutlarında orta düzeyde; 'Teknoloji ve kullanımının öğrencilerin derse ilgisine ve başarı düzeylerine etkileri' ve 'Dersin içsel ve dışsal niteliğine teknoloji etkileri' boyutlarından ise yüksek düzeyde puanlar aldıkları göruilmektedir. Ölçeğin geneline göre bakmak gerekirse, velilerin derslerde teknoloji kullanımına yönelik tutumlarının olumlu düzeyde olduğu söylenebilir. “Teknolojiye Karşı Direnç” ölçeği genelinde, velilerin teknolojiye karşı gösterdikleri direnç orta düzeydedir. Velilerin derslerde teknoloji kullanımına yönelik tutumları olumlu düzeydeyken, teknolojiye karşı gösterdikleri direncin orta düzeyde olması onların salgın döneminde uzaktan eğitim sürecinden yoruldukları yönünde yorumlanabilir. Garbe, Ogurlu, Logan ve Cook'un (2020) çalışmalarında da benzer şekilde bir durum söz konusudur. Ebeveynlerin görüşlerine bakıldığında, teknolojik alet ve araçların eğitimde kullanımını önemsedikleri, ancak COVID-19 salgını sürecindeki uzaktan eğitimde çocuklarının desteklenmesi için okul tarafından verilen online kaynakların sayısı karşısında bunalmış hissettikleri görülmüştür. Ayrıca velilerin teknolojiye karşı direnç göstermelerinin sebebinin, küçük yaş grubundaki çocuklarının uzun süreli olarak teknolojik aletlere maruz 
kalmalarını istememelerinden kaynaklandığı düşünülebilir. Fidan ve Çelik'in (2020) çalışmasında da bu durumu destekleyen ifadelerde bulunulmuştur. Günlük hayatta faydalanılan teknolojik aletlerle çok küçük yaşta tanışan öğrencilerin, veliler tarafından mutlaka uzun süreli kullanım konusunda doğru biçimde yönlendirmelerine ihtiyaç duyulduğu belirtilmiştir.

Velilerin "Derslerde Teknoloji Kullanımına Yönelik Tutum Ölçeği” ve “Teknolojiye Karş1 Direnç Ölçeği puanlarıyla cinsiyet arasında anlamlı bir farklılığa rastlanmamıştır. Ancak, kadınların ortalama tutum puanlarının erkeklere oranla daha yüksek olduğu ve kadınların teknolojiye karşı direnç puan ortalamalarının erkeklerinkiyle eşit olduğu görülmektedir. Buradan çıkarılacak sonuç, öğrencilerin annelerinin derslerde teknoloji kullanımına karşı tutumlarının babalardan daha yüksek olsa da, bunun teknolojiye karşı dirençlerinde babalara göre bir farklılık yaratmadığıdır. Bu durum, özellikle ilkokul seviyesinde annelerin çocukların eğitimleriyle genellikle daha yakından ilgilenmelerinden ötürü, direnç gösterseler bile bir şekilde derslerde teknoloji kullanımının gerekliliğini düşünmelerinden ileri geliyor olabilir. Literatürde de bu sonucu destekler nitelikte çalışmalar bulunmaktadır. Bu çalışmalarda da, derslerde teknoloji kullanımına yönelik, cinsiyet değişkeninin anlamlı bir farklılık göstermediği ifade edilmektedir (Balcı ve Kenar, 2013; Fidan ve Çelik, 2020; Gündüz ve Çelik, 2015; Muhanna ve Nejem, 2013). Ayrıca kadınların erkeklere oranla eğitimde teknoloji kullanımına yönelik tutum puanlarının daha yüksek olduğu çalışmalarda (Bisgin, 2014; Dargut ve Çelik, 2014; Yaman 2007) benzer şekilde görülmektedir. Genç'in (2020) çalışmasında ise, teknolojiye direnç noktasında, üniversite düzeyindeki erkek öğrencilerin kadın öğrencilerden daha fazla uzaktan eğitime yatkın oldukları görülmektedir.

"Derslerde Teknoloji Kullanımına Yönelik Tutum Ölçeği" nin 1, 2, ve 4. alt boyutlarında ilkokuldan mezun olan velilerin puan ortalamaları, lise ve üniversiteden mezun olan velilerinkilere göre anlamlı düzeyde yüksektir. Buradan anlaşıldığı üzere; eğitim düzeyinin artışıyla velilerin derslerde teknoloji kullanımına yönelik tutumları ters orantılı olarak azalma göstermektedir. “Teknolojiye Karşı Direnç Ölçeği”, 'Teknolojik aletleri gereksiz görme' ve ‘Teknoloji kullanımının öğrencilerin konuyu kendi hızlarına göre öğrenmesine ve derse katılma düzeylerine etkileri' boyutları ve ölçek toplam puan ortalamaları arasında istatistiksel olarak anlamlı bir fark bulunmaktadır. İlkokuldan mezun olan velilerin puan ortalamaları, lise ve üniversiteden mezun olan velilerinkilere göre anlamlı düzeyde yüksektir. Bu durum, velilerin teknolojiye karşı dirençlerinin, eğitim düzeyinin artmasıyla ters orantılı olduğunu göstermektedir. Velilerin derslerde teknoloji kullanımına yönelik tutumları ve teknolojiye yönelik dirençleri eğitim düzeyleri artarken azalmaktadır. Eğitim düzeyi arttıkça velilerin teknoloji kullanımına karşı direnç göstermedikleri, teknolojiyi hayatlarına ve dolayısıyla çocuklarının hayatlarına entegre ettikleri görülmektedir. Ancak, pandemi sürecinde ilkokul 
çocuklarının sürekli uzaktan eğitimle iç içe olmalarının, eğitim düzeyi yüksek veliler tarafından olumlu karşılanmadığı sonucuna ulaşılabilir. Bu durum velilerin uzun süreli teknolojik araç kullanımının küçük yaş grubundaki çocukları için olumsuz etkilere yol açacağını düşünmelerinden ötürü olabilir. Nitekim bu durumu destekleyici çalışmalar da literatürde bulunmaktadır (Akgül ve Oran, 2020; Aslanargun, 2007; Çamlıbel-Çakmak, 2010; Fidan ve Çelik, 2020; Putri vd., 2020). Akgül ve Oran'ın (2020) çalışmasında veliler, uzaktan eğitimin çocukları bireyselleştirmesi ve pasifleştirmesi sorunundan bahsetmiştir. Putri vd.'nin (2020) çalışmasında da bu durum veliler tarafından, "Çocuklar uzaktan eğitim süreciyle birlikte sosyal hayatların kaybediyorlar. Okulda arkadaşlarıyla oynayıp etkileşime girebiliyorlardı. Ancak evde durdukça bu durum da değişti." ş̧eklinde ifade edilmiştir.

Mevcut çalışmada, ‘Teknoloji ve kullanımının öğrencinin sosyo-psikolojik gelişimindeki önemi ve rolü' boyutunda; uzaktan eğitimle işlenen hayat bilgisi ve sosyal bilgiler derslerinin "kısmen nitelikli" olduğunu söyleyenlerin; derslerde teknoloji kullanımına yönelik tutum puanı ortalamaları, "nitelikli" olduğunu söyleyen velilerinkilere göre anlamlı düzeyde yüksektir. Buradan çıkarılacak sonuç; veliler hayat bilgisi ve sosyal bilgiler derslerinin uzaktan eğitimde kısmen nitelikli olduğunu düşünseler bile; derslerde teknoloji kullanımının öğrencilerin sosyopsikolojik gelişimi üzerinde olumlu etkisinin olduğunu düşünmektedirler. Ancak Gür'ün (2017) çalışmasında teknolojinin olumsuz etkilerine yönelik tutum puanları incelendiğinde, annelerin teknolojinin sağlık ve psiko-sosyal açıdan olumsuz etkileri noktasında çocuklarını daha fazla sınırlandırdıkları sonucuna ulaşılmaktadır. Çetinkaya ve Sütçü'nün (2016) çalışmasında da, annelerin çocuklarına teknolojiyle ilgili bu noktada kısıtlama getirdikleri sonucuna ulaşılmıştır. Bu farklılık, pandemi dönemi ile birlikte öğrencilerin uzaktan eğitimle ders işlemek zorunda kalmaları sebebiyle, velilerin teknolojinin çocukların sosyo-psikolojik gelişimindeki rolünün daha çok farkına varmaları ile ilgili olabilir. Teknolojiyle daha fazla iç içe olmak zorunda kalan veliler, çocukları için özellikle hayat bilgisi ve sosyal bilgiler dersinde uzaktan eğitimde teknoloji kullanımının yararını fark etmiş olabilirler. Nitekim, Akgül ve Oran'ın (2020) çalışmasında da veliler, çocuklarının uzaktan eğitimle işlenen derslere yönelik olumlu motivasyona sahip olduklarını belirtmiştir. Ayrıca bu durum OECD raporunda da, evde uzaktan eğitimle bir okul ortamı oluşturmanın "öğrencilerin kendi öğrenmelerini yönetme özerkliğinde bir artış" oluşturduğu şeklinde beklenmedik olumlu bir duruma yol açtığı belirtilmiştir (Reimers ve Schleicher, 2020). Dolayısıyla, sosyal bilimler içerikli derslerin uzaktan eğitimle nitelikli biçimde işlenmeleri, çocukların bireysel öğrenmelerinin yanı sıra hayata dair öğrenmelerini olumlu biçimde etkileyen bir unsur olacaktır.

Ayrıca mevcut çalışmada, "Teknolojiye Karşı Direnç Ölçeği" boyutlarında ve tüm ölçekteki puan ortalamaları karşılaştırıldığında ise; genel olarak hayat bilgisi ve sosyal bilgiler 
derslerinin uzaktan eğitim ile "niteliksiz" geçtiğini söyleyen velilerle "kısmen nitelikli" geçtiğini söyleyen velilerin teknolojiye karşı direnç puanlarının daha yüksek olduğu görülmektedir. Buradan çıarılan sonuç da; teknolojiye karşı direnç gösteren velilerin, hayat bilgisi ve sosyal bilgiler derslerinin "niteliksiz ya da kısmen nitelikli" şekilde işlendiğini düşünmelerine yöneliktir. Görülmektedir ki, veliler derslerin nitelikli geçmediğini düşündüklerinde, uzaktan eğitim sisteminde kullanılan teknolojiye karşı direnç göstermektedirler. Başaran, Doğan, Karaoğlu ve Şahin'in (2020) çalışmalarında da, velilerin uzaktan eğitim sürecinde eğitimin aksamamasından ve derslerin devam etmesinden dolayı memnun oldukları belirtilmiştir. Çocuklarına bu hususta destekleyici bir tavır sergiledikleri; bilgisayar ve internet gibi teknoloji kullanımında yardımcı oldukları ifade edilmiştir. Yine İnci-Kuzu'nun (2020) çalışmasında da benzer şekilde, EBA sistemiyle derslerin uzaktan eğitimle işlenmesinin, veliler ve öğrencilerin büyük çoğunluğu tarafından beğenildiği, derslerden geri kalınmadığı ile ilgili olarak da mutlu oldukları sonucuna ulaşılmıştır. Bobb ve Jones' un (2020) çalışmasında ise veliler, öğretmenlerin uzaktan eğitim sürecinde derslerin işlenmesinden sonra çeşitli teknolojik araçlar ile, (özellikle video yoluyla) öğrencilerin tüm sorularına hızlı bir şekilde yanıt vermektedir. Böylece veliler, hem derslerin nitelikli geçtiğini düşünmekte, hem de bu şekilde teknolojiyle iç içe eğitimi yararlı bulmaktadırlar.

Velilerin "Teknolojiye Karşı Direnç" toplam puanları ve derslerde "Teknoloji Kullanımına Yönelik Tutum” ölçeği alt boyutları arasındaki ilişki incelendiğinde, 'Teknoloji ve kullanımının öğrencinin sosyo-psikolojik gelişimindeki önemi ve rolü' boyutu arasında orta düzeyde pozitif yönde ilişki olduğu görülmektedir. Ayrıca, 'Dersin içsel ve dışsal niteliğine teknoloji etkileri' arasında çok zayıf düzeyde negatif yönde anlamlı bir ilişki tespit edilmiştir. Ancak genel olarak boyutlardaki ilişinin negatif yönde olduğu görülmektedir. Bu nedenle, velilerin teknolojiye karşı dirençleri arttıkça, derslerde teknoloji kullanımına yönelik tutumlarında azalma olduğu söylenebilir. "Teknolojiye Karşı Direnç Ölçeği” toplam puanlarında çıkan sonuca göre bu direnç, orta düzeydedir. Bu durum, velilerin salgın süreciyle birlikte uzaktan eğitime geçiş konusunda hazırlıksız yakalanmaları ile ilgili olabilir. Çünkü ülke genelinde bu geçiş konusunda kademeli bir durum yaşanmadığından, ilkokul düzeyindeki öğrenciler ve dolayısıyla veliler için bu sürece hazırlanmak mümkün olamamıştır. Nitekim Gülbahar'ın (2012) çalışmasında üniversite öğrencilerinin uzaktan eğitim sürecinin başarısını etkileyen önemli bir faktörün e-öğrenme sürecine ilişkin hazır bulunuşluk olduğu ifade edilmiştir. Öğrencilerin derslere yönelik motivasyon ve tutumlarında da bu faktörün etkileyen önemli olduğu ortaya konulmuştur. Yaş grubu ilkokul öğrencilerine göre oldukça büyük olan üniversite öğrencilerinde durum böyleyken, ilkokul öğrencilerinde ve velilerinde uzaktan eğitime hazırbulunuşluk olamaması anlaşılabilir bir durumdur. Akgül ve Oran'ın (2020) çalışmasında da, velilerin uzaktan eğitimde birçok alt yapı probleminin olduğunu ifade ettikleri görülmektedir. Veliler, çocuklarının nitelikli 
eğitim alabilmeleri için, uzaktan eğitimde gerekli internet ve teknolojik problemlerin çözülmesi gerektiğini düşünmektedirler. Garbe, Ogurlu, Logan ve Cook (2020) ile Putri vd.'nin (2020) çalışmalarında ise velilerin, salgın sürecinde hem öğrencilerin hem de öğretmenlerin teknolojik problemler yaşadıklarını ifade ettikleri, nitelikli bir eğitim için bunların çözülmesi gerektiğini öne sürdükleri görülmüştür.

\section{SONUÇ VE ÖNERİLER}

Sonuç olarak bakıldığında, velilerin hayat bilgisi ve sosyal bilgiler derslerinin uzaktan eğitimle işlenmesine yönelik tutumlarının olumlu düzeyde olduğu ve teknoloji kullanımına yönelik orta düzeyde direnç gösterdikleri görülmektedir. Yeni bir sisteme geçmek ve buna alışmak, yaşamın her alanında olduğu gibi eğitim alanında da zorluk göstermektedir. İlerleyen günlerde salgının bittiği süreçte de, eğitime dijital yolların entegre edilmesinin yerinde olacağı düşünülmektedir. Aslında teknolojinin bu denli ilerlediği dünyada, senkron ve asenkron olarak uzaktan eğitimin kullanılamaması veya daha az kullanılması bizim eksiğimizdir. Bundan sonraki eğitim sürecinde yüz yüze ve uzaktan eğitimin iç içe geçtiği hibrit bir modelin kullanılması yerinde olacaktır. Bu nedenle başta öğrenciler olmak üzere, öğretmen ve velilerin bu sürece hazırlanmaları, teknolojiye olan tutumlarının olumlu yönde geliştirilmesi ve teknolojiye karşı dirençlerinin azaltılması için çalışmaların yapılması önem taşıyan bir durum olacaktır.

Bu çalışma, 2019-2020 eğitim-öğretim yılında uzaktan eğitim ile işlenen hayat bilgisi ve sosyal bilgiler derslerine yönelik görüş belirten 201 kişiden oluşan veli grubuyla sınırlıdır. Veriler, 'Ailelerin Teknoloji ve Derslerde Teknoloji Kullanımına Yönelik Tutum' ve ‘Teknolojiye Karşı Direnç' Ölçeklerinden elde edilen sonuçlarla sınırııdır.

Bundan sonra yapılacak çalışmalar için aşağıdaki önerilerin uygun olduğu değerlendirilmiştir:

Araştırmanın birinci ve dördüncü alt problemlerinden elde edilen sonuçlara göre, velilerin derslerde teknoloji kullanımına yönelik tutumları olumlu düzeydeyken, teknolojiye karşı gösterdikleri direnç orta düzeydedir. Ayrıca veliler derslerin nitelikli geçmediğini düşündüklerinde, uzaktan eğitim sisteminde kullanılan teknolojiye karşı direnç göstermektedirler. Dolayısıyla velilerin uzaktan eğitim sürecinde teknolojiye yönelik dirençlerini azaltmak için, onlara birtakım online seminerler düzenlenerek derslerin nasıl daha nitelikli hale getirilebileceğine yönelik çalışmaların yapıldığı okullar tarafından gösterilebilir. Ayrıca özellikle bu salgın döneminde, "veli, okul, öğretmen" işbirliğine her zamankinden daha çok önem verilerek uzaktan eğitim süreci daha işlevsel hale getirilebilir.

İkinci alt problemden elde edilen sonuçlara göre; kadınların ortalama tutum puanlarının erkeklere oranla daha yüksek olduğu ve kadınların teknolojiye karşı direnç puan ortalamalarının 
erkeklerinkiyle eşit olduğu görülmektedir. İlkokul düzeyindeki öğrencilerle annelerin daha yakından ilgilendiği düşünüldüğünde, bu durum anlaşılmaktadır. Anneler teknolojiye karşı direnç gösterseler bile, derslerde teknoloji kullanımının gerekliliğini düşünmektedirler. Dolayısıyla babaların da teknolojiye karşı tutum ortalamalarını arttırabilmek için, "uzaktan eğitimde baba programları" oluşturulabilir. Böylece babaların da teknolojiye yönelik olumlu tutumlar göstermeleri yönünde teşvik edici olunabilir.

Üçüncü ve beşinci alt problemden elde edilen sonuçlara göre; eğitim düzeyi arttıkça velilerin teknoloji kullanımına karşı direnç göstermedikleri, teknolojiye yönelik tutumlarının olumlu olarak arttı̆̆1; dolayısıyla teknolojiyi hayatlarına ve çocuklarının hayatlarına entegre ettikleri görülmektedir. Buna ilişkin olarak, eğitim düzeyi üniversite ve üzeri olan velilere online platformlardan sınıftaki diğer velilere sunum yapmaları yönünde görevler verilebilir. Böylece daha düşük eğitim düzeyindeki velilerin teknolojiye yönelik dirençlerini azaltma konusunda adımlar atmalarına yardımcı olunabilir. Böylece kendilerinin de uzaktan eğitim sürecinin önemli bir parçası olduğunu anlayan veliler, derslerde teknoloji kullanımına yönelik dirençlerini azaltabileceklerdir.

\section{KAYNAKÇA}

Adıgüzel, A. (2020). Salgın sürecinde uzaktan eğitim ve öğrenci başarısını değerlendirmeye ilişkin öğretmen görüşleri. Milli Eğitim, 49(Özel Sayı 1), 253-271.

Akbulut-Ünal, C. (2020). İzolasyon sürecinde uzaktan piyano eğitimine yönelik veli değerlendirme sonuçları ve öğrenci not karşılaştırması. İdil Sanat ve Dil Dergisi, 76, 18321840.

Akgül, G., \& Oran, M. (2020). Sosyal bilgiler öğretmenlerinin, ortaokul öğrencilerinin ve öğrenci velilerinin pandemi sürecindeki uzaktan eğitime ilişkin görüşleri. Eğitimde Yeni Yaklaşımlar Dergisi, 3(2), 15-37.

Aslan, C., ve Kan, A. (2017). Yardımcı teknolojilere yönelik tutum ölçeği geliştirme çalışması. Abant İzzet Baysal Üniversitesi Eğitim Fakultesi Dergisi, 17(1), 48-63.

Aslanargun, E. (2007). Okul aile birliği ve öğrenci başarısı üzerine bir tarama çalışması. Sosyal Bilimler Dergisi, 9(18), 119-135.

Balc1, M., \& Kenar, İ. (2013). Tablet PC destekli fen ve teknoloji dersine yönelik öğrenci velilerinin tutumları. Turkish Studies, 8(8), 1687-1702.

Başaran, M., Doğan, E., Karaoğlu, E., ve Şahin, E. (2020). Koronavirüs (Covid-19) pandemi sürecinin getirisi olan uzaktan eğitimin etkililiği üzerine bir çalışma. Academia Eğitim Araştırmaları Dergisi, 5(2), 368-397. 
Berson, I., \& Berson, M. (2005). Challenging online behaviors of youth: findings from a comparative analysis of young people in the US and New Zealand. Social Science Computer Review, 23(1), 29-38.

Bisgin, H. (2014). Analyzing the attitudes of physical education and sport teachers towards technology. Anthropologist, 18(3), 761-764.

Bubb, S., \& Jones, M.A. (2020). Learning from the COVID-19 home-schooling experience: Listening to pupil, parents/carers and teachers. Improving Schools, 23(3), 209-222.

Çalışkan, A. (2019). Değişime direnç: bir ölçek uyarlama çalışması. Süleyman Demirel Üniversitesi İktidasi ve İdari Bilimler Fakültesi Dergisi, 24(2), 237-252.

Çamlıbel-Çakmak, Ö. (2010). Okul öncesi eğitim kurumlarında aile katılımı. Abant İzzet Baysal Üniversitesi Sosyal Bilimler Enstitüsü Dergisi, 20, 1-18.

Çetinkaya, L., \& Sütçü, S. (2016). Çocukların gözüyle ebeveynlerinin bilişim teknolojileri kullanımlarına yönelik kısıtlamaları ve nedenleri. Turkish Online Journal of Qualitative Inquiry, 7(1), 79-116.

Daniel, S. (2020). Education and the COVID-19 pandemic. Prospects, 49, 91-96.

Dargut, T., \& Çelik, G. (2014). Türkçe öğretmeni adaylarının eğitimde teknoloji kullanımına ilişkin tutum ve düşünceleri. Ana Dili Ĕ̆itimi Dergisi, 2(2), 28-41.

Diehl, W. C. (1961). Charles A. Wedemeyer: visionary pioneer of distance education. M. C. Moore (Ed.). Handbook of Distance Education, (38-48). Newyork: Routledge Taylor \& Francis.

Fauzi, I., \& Khusuma, I. (2020). Teachers' elementary school in online learning of covid-19 pandemic condition. Jurnal Iqra': Kajian Ilmu Pendidikan, 5(1), 58-70. https://doi.org/10.25217/ji.v5i1.914.

Fidan, İ., \& Çelik, F. (2020). İlkokul çağı öğrencilerinin ders çalışma sürecinde teknolojik araç kullanımına ilişkin veli görüşleri, İBAD Sosyal Bilimler Dergisi, Milli Mücadelénin 100. Yılı Özel Sayısı, 484-512.

Garbe, A., Ogurlu, U., Logan, N., \& Cook, P. (2020). COVID-19 and remote learning: experiences of parents with children during the pandemic. American Journal of Qualitative Research, 4(3), 45-65.

George, D., \& Mallery, M. (2010). Spss for windows step by step: A simple guide and reference (17.0 update). Boston: Pearson.

Genç, E. (2020). Üniversite öğrencilerinin değişime direnç düzeylerinin uzaktan eğitime yönelik tutumlarına etkisi. Insan ve Toplum Bilimleri Araştırmalar Dergisi, 9(5), 3774-3801.

Gülbahar, Y. (2012). Study of developing scales for assessment of the levels of readiness and satisfaction of participants in e-learning environments. Journal of Faculty of Educational Sciences, 45(2), 119-137. 
Gündüz, S., \& Coşkun-Çelik, H. (2015). Öğrencilerin matematik dersinde akıllı tahta kullanımına yönelik tutumlarının çeşitli değişkenler açısından incelenmesi. Dicle Üniversitesi Ziya Gökalp Eğitim Fakultesi Dergisi, 25,157-174.

Gür, D. (2017). Ortaokul öğrencilerinin bilişim teknolojileri kullanımlarına yönelik ebeveynlerin denetimleri ve tutumlarının çeşitli değişkenler açısından incelenmesi. Yayımlanmamış Yüksek Lisans Tezi, Fırat Üniversitesi Eğitim Bilimleri Enstitüsü, Elazı̆̆.

Hızal, A. (1983). Uzaktan öğretim süreçleri ve yazılı gereçler: Eğitim teknolojisi açısından yaklaşım. Ankara: Sevinç Matbaası.

İnci-Kuzu, Ç. (2020). COVID-19 pandemisi sürecinde uygulanan ilkokul uzaktan eğitim programı (EBA TV) ile ilgili veli görüşleri. Milli Eğitim, 49 (Özel Sayı 1), 505-527.

Kabapınar, Y. (2012). Kuramdan uygulamaya hayat bilgisi ve sosyal bilgiler öğretimi. Ankara: Pegem Akademi.

Karasar, N. (2004). Bilimsel araştırma yöntemi (13. Baskı). Ankara: Nobel Yayın Dağıtım.

Kenar, İ. (2012). Teknoloji ve derslerde teknoloji kullanımına yönelik veli tutum ölçeği geliştirilmesi ve tablet PC uygulanması. Eğitim Bilimleri Araştırmaları Dergisi, 2(2), 123-136.

Livingstone, S., \& Helsper, E. J. (2008). Parental mediation and children's Internet use. Journal of Broadcasting and Electronic Media, 52(4), 581-599.

Milli Eğitim Bakanlığı (MEB). (2018a). Hayat bilgisi dersi öğretim programı (İlkokul 1, 2 ve 3. stnıflar). Ankara: Mili Eğitim Bakanlığı Yayınları.

Milli Eğitim Bakanlığı (MEB). (2018b). Sosyal bilgiler dersi öğretim programı (İlkokul ve ortaokul 4 ve 5, 6, 7. simfflar). Ankara: Mili Eğitim Bakanlığı Yayınları.

Muhanna, W., \& Nejem, K. M. (2013). Attitudes of mathematics teachers toward using smart board in teaching mathematics. Contemporary Issues in Education Research, 6(4), 373-80.

Murphy, C., \& Beggs, J. (2003). Primary pupils and teachers use of computers at home and school. British Journal of Educational Technology, 34(1), 79-83.

Odabaş1, F. (2005). Parent's views on internet use. The Turkish Online Journal of Educational Technology, 4(1), 38-45.

Özdemir, O., \& Celayir, E. (2020). Öğrenci velilerine yönelik teknolojiye karşı direnç ölçeği. Trakya Ĕ̈itim Dergisi, 10(3), 614-631.

Putri, R. S., Purwanto, A., Pramono, R., Asbari, M., Wijayanti, L. M., \& Hyun, C. C. (2020). Impact of the COVID-19 pandemic on online home learning: An explorative study of primary schools in Indonesia. International Journal of Advanced Science and Technology, 29(05), 48094818.

Rosen, L. D., Cheever, N. A., \& Carrier, L. M. (2008). The association of parenting style and child age with parental limit setting and adolescent myspace behavior. Journal of Applied Developmental Psychology, 29, 459-471. 
UNESCO, (2020). Education: From disruption to recovery, https://en.unesco.org/covid19/educationresponse, 25 Mayıs 2020.

Ütkür, N. (2016). Öğretmenlerin kullandıkları yöntem ve teknik farklılıkları: Hayat bilgisi dersi örneği. Abant İzzet Baysal Üniversitesi Eğitim Fakültesi Dergisi, 16 (USBES Özel Sayı II), 16311651.

Etik Kurul Kararı: İstanbul Üniversitesi-Cerrahpaşa Sosyal ve Beşeri Bilimler Araştırmaları Etik Kurulu Onay Belgesi 08.03.2021 tarihinde E-74555795-050.01.04-47991 karar sayısı ile alınmış ve araştırma etik yönden uygun bulunmuştur. 